\title{
Group psychological phenomena and mental health preservation in complex social situations
}

\section{Групові психологічні феномени і збереження ментального здоров'я у складних соціальних ситуаціях}

\author{
Olga Korobanova \\ Ольга Коробанова \\ Інститут соціальної та політичної психології НАПН України, Київ, Україна \\ Політичні та економічні реалії чинять безумовний вплив на життя людей. В \\ сучасній Україні за умов гібридної війни, анексії Криму та воєнної агресії на \\ сході України постає проблема соціально-психологічних факторів \\ збереження ментального здоров’я. У складні соціальні ситуації потрапили \\ різні верстви населення України, серед них внутрішньо переміщені особи, а \\ також пересічні громадяни різного віку. Оскільки всебічний аналіз та оцінка \\ ситуації іiї учасниками, які знаходиться в цій ситуації та переживають іï, \\ утруднена, можливі часткові, подекуди помилкові висновки, якими вони \\ будуть керуватися при виборі певної лінії поведінки.
}

Соціальні ситуації як такі представляють фрагмент соціального життя, який визначається залученими людьми, характером їх взаємин, місцем дії, змістом діяльності (Основи соціальної психології, 2008). Ситуація також $\epsilon$ сукупністю подій, соціальних умов і обставин, у яких опинилися ії̈ учасники та має визначні особливості, які слід враховувати при ії аналізі.

Складну соціальну ситуацію характеризують неспроможність окремої людини або групи людей подолати цю ситуацією самотужки; масштаб та сила впливу на учасників взаємодії; виникнення екстремальних умов, міжособових та соціальних конфліктів, ситуації ризику. Вимірами ситуації, що ускладнюють їі, можуть стати ступінь небезпеки, конфліктності, ворожості оточення. Можливі відчуття «напруженого очікування», незручностей, надмірних фізичних навантажень.

Складність визначає «ситуація неможливості», у якій суб’єкт відчуває неможливість реалізації власних інтенцій та яка описується як стрес, фрустрація, конфлікт та криза (Василюк, 1984). Також до цих видів складних ситуацій слід додати травму як найбільш важку, складну в переживанні людиною ситуацію. Зазначимо, групова динаміка може утворювати континуум від групової напруженості до групової травми.

Складовими емпіричної моделі виникнення групової феноменології вважаємо спрямовані на складну ситуацію когнітивно-перцептивні процеси, визначення та порівняння статусів своєї та «іншої» групи, , порушення рольового балансу, редукція рольового репертуару учасників на тлі включеності у групу, утворення соціальних ілюзій. Неможливість подолати складну ситуацію може травмувати іï учасників або викликати, зокрема, 
явища неточної, «помилкової» перцепції складної соціальної ситуації або ії інтерпретації, та спричиняти виникнення соціальних ілюзій як прояв уходу від нестерпної реальності внаслідок травми.

Зауважимо, що ми відносимо до соціальних ілюзій продукти сприймання членами групи соціально-психологічних ситуацій, в умовах яких відбувається групова взаємодія. Ілюзія - викривлене психічне відображення об’єктивної реальності (Платонов, 1984). Вважаємо соціальні ілюзії продуктами колективного сприймання, у яких неповно або неточно відображується групова реальність: соціальна ситуація взаємодії, групові цілі та цінності, учасники взаємодії. Таким чином, соціальні ілюзії $є$ проявом групового несвідомого, про що може свідчити існування певного протиріччя.

Зокрема, проведене нами дослідження цінностей за методикою М. Рокича, у якому прийняли участь 75 студентів київських вузів віком від 18 до 25 років свідчить про те, що найвищі ранги серед термінальних цінностей зайняли здоров’я (фізичне і психічне) (1), кохання (духовна та фізична близькість 3 коханою людиною) (2), щасливе сімейне життя (3), свобода (самостійність,незалежність в судженнях і вчинках) $(4,5)$, активне діяльне життя (повнота та емоційна насиченість життя) $(4,5)$, розвиток (робота над собою, постійне фізичне та духовне удосконалення) (6), життєва мудрість (зрілість суджень та здоровий глузд, який досягається життєвим досвідом) $(7,5)$, матеріально забезпечене життя (відсутність матеріальних труднощів) $(7,5)$, пізнання (9), краса природи та мистецтва (переживання прекрасного) (10). У дужках наведений груповий ранг тієї чи іншої цінності.

Останні позиції зайняли щастя інших (добробут, розвиток та удосконалення інших людей, всього народу, людства в цілому) (16), суспільне визнання (повага оточуючих, колективу, товаришів по роботі) (17), продуктивне життя (максимально повне використання своїх можливостей, сил та здібностей) (18).

Найвищі ранги серед інструментальних цінностей у проведеному дослідженні зайняли вихованість (1), терпимість (2), життєрадісність (почуття гумору) (3), освіченість (широта знань, висока загальна культура) (4), чесність (правдивість та щирість) $(5,5)$, відповідальність (почуття обов'язку, вміння тримати слово) $(5,5)$, широта поглядів (вміння розуміти чужу точку зору, поважати інші смаки, звичаї, звички) (7), тверда воля (вміння настояти на своєму, не відступати перед труднощами) (8), раціоналізм (вміння реально та логічно мислити, приймати обдумані, раціональні рішення) (9), чуйність (10). На останні позиції вийшли дисциплінованість (16), незалежність (17), непримиримість до недоліків в собі та інших (18).

Зазначимо, що цінності вихованості, терпимості, життєрадісності та освіченості змальовують портрет позитивної вихованої молодої людини, приємної у спілкуванні, слухняної та толерантної. Проте, як показники переконань молодих людей в тому, що певний образ дій або властивість особистості є переважними в будь-якій ситуації, вони справляють враження 
неможливості за їх рахунок досягти цінностей-цілей, оскільки не приведуть ані до здоров'я, ані до щасливого сімейного життя, ані до свободи, не допоможуть зберегти кохання.

В груповому полі соціальної взаємодії багато неусвідомленого. Відсутні причинно-наслідкові зв'язки та узгодженість між переважними груповими цінностями-цілями та цінностями - засобами їх досягнення Так, сміливість у відстоюванні своєї думки (посідає ранг 14,5) і незалежність (займає ранг 17) серед інструментальних цінностей, в той час, як у термінальних цінностях свобода (самостійність, незалежність в судженнях і вчинках) посідає високий ранг $(4,5)$.

У той же час, цінності щастя інших (добробуту, розвитку та удосконалення інших людей, всього народу, людства в цілому) (ранг 16), суспільного визнання (отримання поваги оточуючих, колективу, товаришів по роботі) (ранг 17), а також продуктивного життя (як максимально повного використання своїх можливостей, сил та здібностей) (ранг 18) посідають останні місця серед термінальних цінностей в молодих людей, які прийняли участь у досліджуванні.

На основі отриманих результатів, можна говорити про сформованість у молоді системи цінностей, наявність яких в учасників соціальної взаємодії сприятиме взаєморозумінню та полегшить виконання спільних дій. Разом 3 тим, можна вважати, що пріоритетні цінності-засоби не ведуть до досягнення цінностей-цілей, що можна, на нашу думку, вважати проявом однієї з соціальних ілюзій.

Людська властивість видавати бажане за дійсне та перетворювати прагнення і бажання на мотиви реальних дій може лежати в основі виникнення соціальних ілюзій. Так, наші дослідження показали, що у сприйманні іншого члена групи, якому учасник симпатизує, він ідентифікується 3 ним та сприймає приємного іншого подібним собі. Схожість між рисами «Я» і рисами «симпатичного іншого» простежується у кореляційному зв’язку між ними і є значущою на рівні 0,01 (Свідоме і несвідоме у груповій взаємодії, 2018). Превалювання настановлення приписувати симпатичному одногрупникові риси образу «Я», схожі на власні, певним чином, також можна вважати проявом соціальної ілюзії.

Соціальні ілюзії і іх зв’язок з груповими феноменами вимагають докладного подальшого дослідження. На даному етапі поки що неможливо дати відповідь, чи є виникнення соціальних ілюзій захисним механізмом, втечею від реальності (у мрії, бажання) у складних ситуаціях або лише проявом функціювання групового несвідомого, якому властиві свої особливості.

Ключовими показниками вияву групових психологічних феноменів є: порівняльні статуси своєї і «чужої» групи, підміна реальності соціальніими ілюзіями, рольові преференції членів групи на тлі включеності у групу, а також мотивація соціальної поведінки. Порівнюючи статус своєї і іншої групи, член групи може надати переваги власній групі, а може піддатися ефекту ореола, коли інша група (наприклад, група студентів старшого курсу) 
набуває вищий статус порівняно з власною групою приналежності. Таким чином, члени групи можуть наділяти високим або низьким статусом свою групу у порявнянні з іншою.

Рольові преференції після пережитих складних ситуацій набувають змін (зокрема, за нашими даними, після подій Майдану підвищилася оцінка психологічних ролей «спостерігача», «новатора», «політпротестуючого» або «абсентеїста» (перераховані у порядку зниження значущості). Включеність можна охарактеризувати як особливий соціально-психологічний механізм актуалізації суб’єктних властивостей членів групи і утворення групи як цілісного об’єднання. Включеність у групову взаємодію визначимо як входження людини у систему вимог, норм, ролей, прав, обов'язків і очікувань, які пред’являють до нього група. Разом з тим у групових процесах слід мати на увазі як існування громадської (колективної) думки, так і існування групового несвідомого, що точить непрогнозований вплив на групову поведінку. Групові феномени виникають на тлі прояву несвідомих тенденцій у поведінці (зниженні або розсіянні уваги, втомі, сильних емоціях, потребі швидко реагувати на загрозу, підвищеній важкості завдань та т. ін.).

Як наслідок анексії Криму і військових дій на Донбасі частина населення покинула свої будинки на постійному місці проживання і оселилася на нових місцях. Внутрішньо переміщені особи, безумовно, знаходяться в епіцентрі складної соціальної ситуації, триває процес адаптації. Втім, таким було їх рішення щодо зміни складної ситуації на краще, коли вони зорієнтувалися в ній.

Зокрема, проведені нами глибинні інтерв’ю з колишніми мешканцями міст Луганська та Донецька допомогли виявити, що ситуації, об’єктивно наділені складнощами і ознаками певної неможливості, разом з тим, можуть не сприйматися учасниками, які наділені достатніми інтелектуальними та емоційними ресурсами, а також мають групову підтримку, як складні. Так, вони відчували напруження i стресові переживання, що допомогло активізувати їх адаптаційні можливості. Відтак, вважаємо, що розроблення засобів психологічної допомоги соціальним суб'єктам, що переживають труднощі групової взаємодії у складних соціальних ситуаціях, має лежати, в тому числі, у площині підвищення їхніх особистих ресурсів і підтримк 3 боку принаймні однієї референтної нрупи.

Співробітниками лабораторії психології малих груп і міжгрупових відносин було здійснене теоретичне обгрунтування процесів породження групових феноменів, спричинених складними соціальними ситуаціями (Chorna, Gornostai, Tsyhanenko, Pletka, Korobanova, Vus, 2018). Під час групової взаємодії в складних соціальних ситуаціях виникають переживання членів групи, які можуть знаходити вияв у груповій напруженості, груповій диференціації, рольових преференціях, появі мікрогруп, як складових групової динаміки. Виникнення групових феноменів, таких як внутрішньогруповоий фаворитизм, міжгрупова дискримінація, соціальна фасилітація, конформізм, групове мислення та ін. на певний час послаблюють це відчуття напруженості, знижують конфліктність. 
Групові психологічні феномени несуть певну захисну функцію, і виникають не завжди, а за певних умов. Зокрема, міжгрупова дискримінація може виникати у відповідь на агресивні впливи. Внутрішньогруповий фаворитизм вимагає для появи певного ціннісного аксіологічного підгрунтя і проявляється поряд 3 груповою підтримкою. При цьому вплив складної ситуації на групову феноменологію залежить від її смислової інтерпретації учасниками та приводить до проявів групової динаміки, як от змін у розмірі інгруп та діапазоні рольового репертуару їх учасників. Групові феномени виникають як відображення групової динаміки; на момент виникнення та функціювання групові феномени знижують групову напруженість. Групові феномени виникають на тлі прояву несвідомих тенденцій у поведінці (зниженні або розсіянні уваги, втомі, сильних емоціях, потребі швидко реагувати на загрозу, підвищеній важкості завдань та т. ін.).

Групові феномени підсилюються, коли занурені у непросту ситуацію члени групи не здатні всебічно проаналізувати ситуацію, змоделювати подальші дії, спрямовані на подолання складності ситуації, а також відрефлексувати рольові паттерни поведінки у змінюваній ситуації. Підвищується включеність до інгруп, пов'язана з прагненням отримати групову підтримку, отримати підтвердження типовості своїх поведінкових та емоціональних реакцій на складну ситуацію та їхню відповідність реакціям інших членів групи. В умовах складних соціальних ситуацій та під їх безпосереднім впливом відбувається динаміка процесів групової інтеграції та диференціації, а саме, зменшення або збільшення мікрогруп, редукція рольового репертуару учасників.

Низка інгрупових та аутгрупових феноменів $\epsilon$ реакцією людей на присутність інших, а також $\epsilon$ механізмами функціонування груп, посередством яких здійснюються групові процеси і досягаються групові стани, які забезпечують інтеграцію індивідуальних дій у спільній груповій діяльності i спілкуванні. Серед них міжгрупова дискримінація, внутрішньогруповий фаворитизм, соціальна фасилітація, конформізм, групове мислення, групова поляризація та ін.

Групова ідентичність, в основі якої є розподіл на «Ми» і «Вони», має на крайньому полюсі міжгрупову дискримінацію, яка передбачає міжгрупові конфлікти (дослідження М. Шеріфа), міжгрупову ворожість, агресію, негативні аутгрупові стереотипи. При цьому найпоширенішими серед імпліцитних моделей консолідації $\epsilon$ «протестні» моделі гуртування в боротьбі проти спільного ворога, зовнішньої загрози і т. ін. (Петрунько, 2014)

Метою міжгрупової дискримінації може бути встановлення відмінності між групами на користь власної (Г. Теджфел). Проте дослідження (Кондратьев, Емельянова, 2011) свідчить про диференційований прояв даного феномену в студентському середовищі та його статусно-референтний характер.

Внутрішньогруповий фаворитизм (солідарність) може бути обумовлений реальною загрозою, більш повним усвідомленням власної групової 
ідентичності та непроникністю групових меж, (Уайт, Самнер, Шеріф, Козер), ситуаціями конкуренції та протистояння між групами. Сутність внутрішньогрупового фаворитизму у підсиленні згуртованості і підтримки всередині групи. За нашими даними, груповий фаворитизм означується спільними цінностями, що сповідує група, спільними аксіологічними засадами, загальнолюдськими принципами, як от справедливості, рівних прав. О. Ю. Дроздов (2014), порівнюючи образи України і Росії в геополітичній свідомості студентів, встановив, що військовий конфлікт істотно погіршив образ Росії, натомість образ України поліпшився лише частково, таким чином, механізм міжгрупової дискримінації в масовій геополітичній свідомості діє сильніше, ніж внутрішньогруповий фаворитизм

У складних ситуаціях, коли учасники відчувають власну некомпетентність, недостатню інформованість, розгубленість або невпевненість, підвищується їхній конформізм, як схильність прислуховуватися до думки групи у збиток власній думці під впливом групового тиску (С. Аш). Деякі автори підкреслюють значення у прояві людиною конформізму відсутності власної думки у певних ситуаціях (Озерова, 2017). Схильність відреагувати на дії іншого аналогічною поведінкою, розглядається деякими психологами як взаємність (Д. Бургун).

Зазначимо, що на прояв конформізму людиною впливає високий статус інших членів групи та характер ситуації, яку вона переживає. Невизначеність ситуації, неясність та багатозначність інформації сприяють орієнтації людини на думки інших людей. Наші дані свідчать, що деякі особи, які нещодавно покинули непідконтрольну Україні територію, багаторазово змінюють судження про українців, нацгвардійців, мешканців Донбасу, на полярні, протилежні за змістом, ніби у пошуках слушної думки, яку схвалює та група, у якій вони наразі присутні.

Також у дослідженнях груп внутрішньо переміщених осіб виявлено, що учасників цих груп легко «звернути з шляху істини», вони легко змінюють власну думку та слухняно приймають запропонований напрямок дій та оцінок, прагнуть не виділятися серед інших.

Групове мислення (схильність членів групи погоджуватися з більшістю або лідером групи, та на основі цього приймати важливі рішення) виникає в ситуації, коли пошук згоди переважає над реалістичною оцінкою можливих дій (I. Джейніс, 1972). При цьому висока ступінь залученості до системи групових уявлень та цінностей може заважати прийняттю правильного рішення. Зокрема, групове мислення знаходить прояв в оцінці подій на сході учасниками: $є$ свідчення, що ті, що залишилися у зоні відчуження, знаходять аргументи, виправдовуючі їхнє рішення.

Серед наративів учасників подій на сході зустрічаємо описи «стокгольмського синдрому» як ідентифікації з тими, хто чинить насилля та прагнення виправдовувати їх.

У складних соціальних ситуаціях групи людей потрапляють в поле дії сил, що спричинюють феномени міжгрупової дискримінації, 
внутрішньогрупового фаворитизму, конформізму, групового мислення, оціальної фасилітації та ін.

\section{Література.}

Василюк Ф.Е. Психология переживания. Анализ преодоления критических ситуаций. М.: Изд-во МГУ, 1984. - 200 с.

Дроздов О. Ю. Динаміка геополітичних уявлень молоді на тлі російськоукраїнського конфлікту 2014 року / О. Ю. Дроздов // Проблеми політичної психології: зб. наук. праць. - К.: Міленіум, 2014. - Вип. 1 (15). - C. 258-266.

Кондратьев М.Ю. Социально-психологические особенности взаимосвязи самооценки и личностно-ролевой взаимопредставленности студентов / М.Ю. Кондратьев, Е.В. Емельянова// Социальная психология и общество. - 2011. - №1. - С. 56 - 73.

Основи соціальної психології: Навчальний посібник / О.А.Донченко, М.М.Слюсаревський, В.О.Татенко, Т.М.Титаренко, Н.В.Хазратова та ін.; За ред. М.М.Слюсаревського. - К.: Міленіум, 2008. - 496 с.

Петрунько О. В. Імпліцитні моделі консолідації громадської думки у свідомості студентської молоді / О. В. Петрунько // Проблеми політичної психології: зб. наук. праць. - К.: Міленіум, 2014. - Вип. 1 (15). - C. 75-86.

Свідоме і несвідоме у груповій взаємодії: монографія / [П.П.Горностай, О.Л.Коробанова, О.Т.Плетка, Г.В.Циганенко, Л.Г.Чорна]; за наук.ред. П.П.Горностая. - Кропивницький, Імекс-ЛТД, 2018. - 244 с.

Gornostai P., Chorna L., Vus V., Tsyhanenko H., Pletka O., Korobanova O. (2018)/ Mental Health: Dislocation of the Concept in the Small Group / Mental Health: Global Challenges of XXI century/ MNCG Journal. Pp/ 18 - 20. Rome. Retrived from: http://www.mhcgj.org/mental-healthdislocation-of-the-concept-in-the-small-group/ [in English]. 